\title{
Characterization of antimicrobial susceptibility, extended-spectrum $\beta$-lactamase genes and phylogenetic groups of Shigatoxin producing Escherichia coli isolated from patients with diarrhea in Iran
}

\author{
Erfaneh Jafari ${ }^{1,2}$ (B), Mana Oloomi ${ }^{1}$ a and Saeid Bouzari ${ }^{1,2^{*}}$ (B)
}

\begin{abstract}
Background: Shiga toxin-producing Escherichia coli (STEC) are among common foodborne bacterial pathogens and healthy livestock are the main source of this bacterium. Severe diseases attribute to two types of cytotoxin Stx1 and Stx2, which are also called Shiga toxin (Stx). Infection of humans with STEC may result in Acute diarrhea with or without bleeding, hemorrhagic colitis (HC) and the hemolytic uremic syndrome (HUS). As antibiotic resistance is increasingly being reported among STEC isolates obtained from livestock and patients worldwide, in this study the pattern of antibiotic resistance in clinical isolates was determined.

Methods: Stool samples were collected from patients with diarrhea. All samples were cultured and identified by biochemical and molecular tests. Antimicrobial susceptibility test and assessment of extended-spectrum $\beta$-lactamase (ESBL)-related genes were conducted. Moreover, phylogenetic groups were analyzed using quadruplex PCR, and DNA analysis assessed multi-locus sequence types (MLST).

Results: Out of 340 E. coli samples, 174 were identified as STEC by PCR. Antimicrobial susceptibility test results showed that, $99.4 \%, 96 \%$ and $93.1 \%$ of isolates were susceptible to imipenem/ertapenem, piperacillin-tazobactam and amikacin, respectively. The highest resistance was towards ampicillin (68.4\%), followed by trimethoprim-sulfamethoxazole (59.8\%), and tetracycline (57.5\%). A total of 106 (60.9\%) isolates were multidrug resistance (MDR) and $40.8 \%$ of isolates were determined to be extended spectrum $\beta$-lactamase producers. In $94.4 \%$ of isolates, genes responsible for ESBL production could be detected, and blaTEM was the most prevalent, followed by blaCTX-M9. Furthermore, phylogenetic grouping revealed that majority of STEC strains belonged to Group C, followed by Groups E, B2 and A. MLST unveiled diverse ST types.
\end{abstract}

Conclusion: A periodical surveillance studies and thorough understanding of antibiotic resistant profiles in STEC isolates could help select effective antibiotic treatment for patients and develop strategies to effectively manage food contamination and human infections.

Keywords: STEC, Multi-drug resistance, Extended-spectrum $\beta$-lactamase, Phylogenetic groups, MLST

\footnotetext{
*Correspondence: saeidbouzari@yahoo.com

${ }^{1}$ Molecular Biology Department, Pasteur Institute of Iran, Tehran, Iran

Full list of author information is available at the end of the article
}

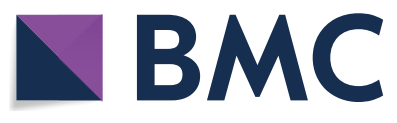

(c) The Author(s) 2021. This article is licensed under a Creative Commons Attribution 4.0 International License, which permits use, sharing, adaptation, distribution and reproduction in any medium or format, as long as you give appropriate credit to the original author(s) and the source, provide a link to the Creative Commons licence, and indicate if changes were made. The images or other third party material in this article are included in the article's Creative Commons licence, unless indicated otherwise in a credit line to the material. If material is not included in the article's Creative Commons licence and your intended use is not permitted by statutory regulation or exceeds the permitted use, you will need to obtain permission directly from the copyright holder. To view a copy of this licence, visit http://creativeco mmons.org/licenses/by/4.0/. The Creative Commons Public Domain Dedication waiver (http://creativecommons.org/publicdomain/ zero/1.0/) applies to the data made available in this article, unless otherwise stated in a credit line to the data. 


\section{Background}

Shiga toxin-producing Escherichia coli (STEC), including O157:H7 and non-O157 serotypes, are among common foodborne pathogens. Outbreaks of several human gastrointestinal diseases, including acute diarrhea with or without bleeding, hemorrhagic colitis ( $\mathrm{HC}$ ) and the hemolytic uremic syndrome (HUS), are caused by STEC $[1,2]$. The elderly and children are more plausible to serious complications caused by this bacterium [2]. Healthy livestock, especially cattle, are the main reservoir of STEC and human infection is often due to contamination of food or water resources [2, 3]. Human virulent STEC produce two types of Shiga toxin (Stx), Stx1 and Stx2 which each have different variants. This bacterium may also contain other virulence factors such as intimin (eae), that is involved in creating attaching and effacing (A/E) lesions $[2,3]$. In cases attributed to STEC, antibiotics should not be administrated as they may lead to bacterial lysis and raised production of Stx and also increased number of antibiotic-resistant strains [2].

In recent years, due to extensive application of various antibiotics (such as $\beta$-lactams) against infections, high levels of antibiotic resistance and extended-spectrum beta-lactamase (ESBL)-producing bacteria are being detected [4]. Extended-spectrum beta-lactamases are specific enzymes produced by Enterobacteriaceae. Their common spread mechanism is by horizontal gene transfer and can be bacterial chromosome and plasmid mediated [5]. The main groups of ESBL enzymes include Class A, C or D enzymes which are generally inhibited by clavulanic acid or tazobactam. The plasmid mediated Class A $\beta$-lactamase, including TEM, SHV, and CTX-M, and chromosomally mediated Class D $\beta$-lactamase OXA are the most predominant among Enterobacteriaceae [6]. The plasmids that contain the ESBL genes are also often encoded with different classes of antibiotics [7], which lead to the development of multidrug resistant (MDR) strains.

Escherichia coli clinical strains have been classified into several phylogenetic groups (A, B1, B2, C, D, E, and F), based on the combination of certain genes and a DNA fragment (chuA, yjaA, arpA genes and TspE4.C2) [8]. Evaluation of the relationship between pathogenicity and phylogeny also demonstrated that the strains belonging to different phylogroups are associated with the source of isolation [8]. The commensal E. coli strains usually belong to groups A and B1 [9], whereas virulent extra-intestinal strains mainly belong to groups B2 and to a lesser extent, to group D [10]. Phylogenetic characterization of E. coli clinical strains provides information about the relation of strains and disease and frequency of their occurrence in the environment. But compared to Uropathogenic $E$. coli, few studies have determined phylogenetic groups of diarrheagenic E. coli. Also the Clermont triplex PCR method, which is only capable of determining phylogroups A, B1, B2, and D, has been used more extensively. Therefore, as disposition of phylogroups for diarrheagenic E. coli is still unclear, STEC could belong to any of the phylogroups [11].

As antibiotic resistance is increasingly being reported among STEC isolates obtained from livestock and patients worldwide, and death is specifically associated to antibiotic-resistant STEC strains, in this study the pattern of antibiotic resistance, as well as ESBL production and phylogenetic groups associated with clinical isolates, was determined.

\section{Materials and methods}

\section{Sampling and processing}

During 1-year period (2014), diarrhea patients' stool samples inoculated on MacConkey agar were collected from different reference hospitals. Following standard microbiological techniques [12], 340 samples from patients ages between 5 months to 92 years old had been biochemically confirmed as E. coli. Five colonies from each of the confirmed isolates' MacConkey agar plate tested by PCR to identify the presence or absence of $s t x 1 A$, stx $2 A$, and eae genes $[13,14]$. Escherichia coli strain $\mathrm{O} 157 / \mathrm{H} 7$ was used as a positive control. Non-pathogenic E. coli strain DH5 $\alpha$ was used as negative control to monitor PCR contamination. All E. coli isolates were submitted to DNA extraction by boiling method as follows: $1 \mathrm{ml}$ from overnight cultures of each colony was centrifuged at $12000 \mathrm{rpm}$ for $2 \mathrm{~min}$. The supernatant was discarded, and the pellet was washed with $1 \mathrm{ml}$ of normal saline by centrifugation at $12000 \mathrm{rpm}$ for $1 \mathrm{~min}$. The pellet was resuspended in $200 \mu \mathrm{l} \mathrm{DNase/RNase}$ free distilled water (ThermoScientific) and subjected to boiling at $100{ }^{\circ} \mathrm{C}$ for $10 \mathrm{~min}$. After centrifugation at $14000 \mathrm{rpm}$ for $2 \mathrm{~min}, 50 \mu \mathrm{l}$ of supernatant was collected to be used as template. The detection of virulence genes were carried out under the following PCR conditions: $95{ }^{\circ} \mathrm{C}$ for $3 \mathrm{~min}, 30$ cycles of $94{ }^{\circ} \mathrm{C}$ for $1 \mathrm{~min}, 60^{\circ} \mathrm{C}$ for $45 \mathrm{~s}, 72{ }^{\circ} \mathrm{C}$ for $45 \mathrm{~s}$, and a final extension at $72{ }^{\circ} \mathrm{C}$ for $5 \mathrm{~min}$.

\section{Antimicrobial susceptibility testing}

Antimicrobial susceptibility tests were performed on Mueller-Hinton agar (Himedia, India) using commercial antimicrobial discs (BD BBL, USA), based on standard disk diffusion method and according to the guidelines of the clinical and laboratory standards institute (CLSI) [15]. The antibiotic discs were ampicillin $(10 \mu \mathrm{g})$, amikacin $(30 \mu \mathrm{g})$, ceftazidime $(30 \mu \mathrm{g})$, cefotaxime $(30 \mu \mathrm{g})$, ciprofloxacin $(5 \mu \mathrm{g})$, ertapenem $(10 \mu \mathrm{g})$, imipenem $(10 \mu \mathrm{g})$, levofloxacin $(5 \mu \mathrm{g})$, piperacillin-tazobactam $(100 \mu \mathrm{g}+10 \mu \mathrm{g})$, tetracycline $(30 \mu \mathrm{g})$ and trimethoprim-sulfamethoxazole 
$(1.25 \mu \mathrm{g}+23.75 \mu \mathrm{g})$. Multidrug resistance was defined by discerning non-susceptibility to at least 1 antibiotic in $\geq 3$ antimicrobial categories [16]. Escherichia coli ATCC 25922 was used for quality control. Detection of ESBLs was performed by combined disc assay [15], using ceftazidime $(30 \mu \mathrm{g})$ and cefotaxime $(30 \mu \mathrm{g})$ discs, alone and in combination with clavulanic acid $(10 \mu \mathrm{g})$. The production of ESBL was determined by the expansion of $\geq 5 \mathrm{~mm}$ of the zone diameters of combined discs compared to ceftazidime and cefotaxime zones.

\section{Molecular identification of ESBL producing strains}

PCR was performed to detect $\beta$-lactamase genes blaCTX-M9, blaSHV, blaOXA and blaTEM using primer sequences presented in Table 1 [17-20]. The PCR procedure was carried out in a total volume of $25 \mu \mathrm{l}$, using $12 \mu \mathrm{l}$ of Taq DNA Polymerase Mix Red- $\mathrm{Mgcl}_{2}$ $2 \mathrm{mM}$ (Ampliqon), $9 \mu \mathrm{l}$ of DNase/RNase free distilled water (ThermoScientific), $1 \mu \mathrm{l}$ of $10 \mathrm{pM}$ for reverse and forward primers, and $2 \mu \mathrm{l}$ of DNA template.

\section{Identification of phylogroups}

All STEC strains were appointed to a phylogenetic group (A, B1, B2, C, D, E or F) based on Clermont's quadruplex multiplex PCR scheme [8]. Genomic DNA of the isolates was used. Instead of the DNA template, water was used as negative control. Agarose gel electrophoresis of the PCR product was carried out in $2 \%$ agarose gel containing DNA Gel dye.

Table 1 Primer sequences and sizes of PCR products

\begin{tabular}{|c|c|c|c|}
\hline Target GENE & Amplicon size (bp) & Primer Sequence ( $5^{\prime}$ to $\left.3^{\prime}\right)$ & References \\
\hline \multicolumn{4}{|l|}{ Virulence genes } \\
\hline \multirow[t]{2}{*}{ StxiA } & 244 & F: CGATGTTACGGTTTGTTACTGTGACAGC & [13] \\
\hline & & R: AATGCCACGCTTCCCAGAATTG & \\
\hline \multirow[t]{2}{*}{$S t \times 2 A$} & 324 & F: GTTTTGACCATCTTCGTCTGATTATTGAG & [13] \\
\hline & & R: AGCGTAAGGCTTCTGCTGTGAC & \\
\hline \multirow[t]{2}{*}{ eae } & 570 & F: AGGCTTCGTCACAGTTG & [14] \\
\hline & & R: CCATCGTCACCAGAGGA & \\
\hline \multicolumn{4}{|l|}{$\beta$-lactamase genes } \\
\hline \multirow[t]{2}{*}{ blactX-M9 } & 856 & F: GTGACAAAGAGAGTGCAACGG & {$[17]$} \\
\hline & & R: ATGATTCTCGCCGCTGAAGCC & \\
\hline \multirow[t]{2}{*}{ blaSHV } & 768 & F:TCGCCTGTGTATTATCTCCC & [18] \\
\hline & & R: CGCAGATAAATCACCACAATG & \\
\hline \multirow[t]{2}{*}{ blaOXA } & 438 & F: GCGTGGTTAAGGATGAACAC & [19] \\
\hline & & R: CATCAAGTTCAACCCAACCG & \\
\hline \multirow[t]{2}{*}{ blaTEM } & 963 & F: GCGGAACCCCTATTTG & {$[20]$} \\
\hline & & R: ACCAATGCTTAATCAGTGAG & \\
\hline \multicolumn{4}{|l|}{ Phylogenetic genes } \\
\hline \multirow[t]{2}{*}{$c h u A^{a}$} & 288 & F: ATGGTACCGGACGAACCAAC & [8] \\
\hline & & R: TGCCGCCAGTACCAAAGACA & \\
\hline \multirow[t]{2}{*}{$y j a A^{\mathrm{a}}$} & 211 & F: CAAACGTGAAGTGTCAGGAG & [8] \\
\hline & & R: AATGCGTTCCTCAACCTGTG & \\
\hline \multirow[t]{2}{*}{$\operatorname{arp} A^{a}$} & 400 & F: AACGCTATTCGCCAGCTTGC & {$[8]$} \\
\hline & & R:TCTCCCCATACCGTACGCTA & \\
\hline \multirow[t]{2}{*}{ TspE4.C2 ${ }^{\mathrm{a}}$} & 152 & F: CACTATTCGTAAGGTCATCC & {$[8]$} \\
\hline & & R: AGTTTATCGCTGCGGGTCGC & \\
\hline \multirow[t]{2}{*}{$\operatorname{arp} A_{-g p E}$} & 301 & F: GATTCCATCTTGTCAAAATATGCC & [8] \\
\hline & & R: GAAAAGAAAAAGAATTCCCAAGAG & \\
\hline \multirow[t]{2}{*}{$\operatorname{trp} A_{-g p c}$} & 219 & F: AGTTTTATGCCCAGTGCGAG & {$[8]$} \\
\hline & & R:TCTGCGCCGGTCACGCCC & \\
\hline \multirow[t]{2}{*}{ trpA_-Internal control } & 489 & F: CGGCGATAAAGACATCTTCAC & [8] \\
\hline & & R: GCAACGCGGCCTGGCGGAAG & \\
\hline
\end{tabular}

${ }^{a}$ Quadruplex 


\section{Multi-locus sequence typing (MLST)}

Although MLST is one of the choice methods for typing of epidemiologically important strains, but as it is a costly and time-consuming technique, only a fraction of the E. coli pathogenic isolates were selected to perform the test. Pasteur MLST system was carried out by amplifying eight house-keeping genes (dinB, icdA, pabB, polB, putP, trpA, trpB,and uidA) from E. coli chromosomal DNA. The amplified products were purified and subjected to Sanger dideoxy DNA sequencing (Microsynth, Switzerland). To determine sequence types (STs), the sequences of these genes were then compared with known alleles at each locus, which are available from Institute Pasteur's MLST website, at www.pasteur.fr/mlst.

\section{Data analysis}

Comparison of proportions and graphic were performed with IBM SPSS 19.0 software and Microsoft Excel (Microsoft Cooperation, 2010). Pearson Chi-square test was used to determine the difference in resistance between ESBL positive and ESBL negative isolates. A two-sided $P$-values $<0.05$ were considered statistically significant. Descriptive statistics such as frequency and percentage were also used to indicate categorical data.

\section{Results}

\section{Sample characteristics}

In total, $340 \mathrm{E}$. coli isolates were tested for stx $1 A$, stx $2 A$ and eae genes using PCR; from which STEC's virulence genes were detected in 174 (51.2\%) of diarrhea cases. Frequency of virulence factors among confirmed samples was as follows; stx1 171 (98.3\%), stx2 10 (5.7\%), eae 16 (9.2\%), and five different virulence profiles were observed i.e., 148 (85.0\%) isolates showed only stx1 gene, 15 (8.6\%) were positive for $s t x 1$ and eae, 7 (4.0\%) for st $x 1$ and $s t x 2$, 3 (1.7\%) for $s t x 2$ and only one of the isolates was positive for all 3 genes. Moreover, the positive cases comprised of 97 males and 77 females with male: female ratio of 1.26:1; from which 44 male and 27 female belonged to children under 6 years, 27 male and 25 female belonged to 10-30 year olds, and the rest of the isolates were from patients older than 30 years (Table 2).

\section{Antibiotic resistance profile}

Based on the evaluation of antibiotic susceptibility pattern against 11 antimicrobial agents (Table 3), among the 174 STEC isolates, $20.1 \%$ were sensitive to all tested antibiotics, and $79.9 \%$ showed resistance to at least one antibiotic. From these isolates, $60.9 \%$ exhibited MDR profile and $40.8 \%$ were ESBL producers. The resistance to ampicillin, trimethoprim-sulfamethoxazole and tetracycline was highly prevalent $(68.4 \%, 59.8 \%$ and $57.5 \%$, respectively); whereas resistance rate to cefotaxime, ceftazidime, ciprofloxacin and levofloxacin were lower than $45 \%$. Sensitivity toward imipenem and ertapenem, were 99.4\% and more than $90 \%$ of isolates were also susceptible to piperacillin-tazobactam, and amikacin. All ESBL producing isolates had high rates of resistance toward cefotaxime and ampicillin, while being susceptible to imipenem and ertapenem. Significantly, the rates of resistance to cefotaxime $(98.6 \%$ vs. $6.8 \%)$, ceftazidime $(62.0 \%$ vs. $4.9 \%)$, levofloxacin ( $45.1 \%$ vs. $9.7 \%)$, and ciprofloxacin (42.4\% vs. $13.6 \%)$ were higher in ESBL + isolates than in ESBL- isolates.

A total of 106 isolates were considered as multidrug resistance, from which 43 (40.6\%), 36 (33.9\%) and 27 (25.5\%) belonged to 3, 4 and 5 classes of antibiotics, respectively. The isolates resistance pattern ranged from 3 to 7 antibiotics and showed 20 different profiles that are shown in Table 4. Among MDR isolates, $40.6 \%$ belonged to children $\leq 6$ year, and $64.2 \%$ were ESBL producers. The frequency of 3,4 and 5 antibiotic groups in MDR ESBL positive strains was 13 (19.1\%), 29 (42.7\%) and 26 (38.2\%), respectively.

\section{Antibiotic resistance genes}

Four genes responsible for $\beta$-lactamase production have been investigated by PCR from 71 ESBL positive phenotypes. The results showed 67 (94.4\%) isolates contained at least 1 of these ESBL encoding genes. The blaTEM gene was more common with frequency of 60 (84.5\%), followed by blaCTX-M9 gene 49 (69.0\%), blaSHV gene 35 (49.3\%), and blaOXA gene 28 (39.4\%). Molecular evaluation of ESBL-producing isolates indicates 4, 3, 2 and 1 gene patterns $(4.2 \%, 16.9 \%, 42.3 \%$ and $31.0 \%$, respectively). The

Table 2 Demographic characteristic of patients

\begin{tabular}{|c|c|c|c|c|c|}
\hline \multicolumn{2}{|l|}{ Variables } & \multirow{2}{*}{$\begin{array}{l}\text { All Samples }(n=340) \\
184(54.1)\end{array}$} & \multirow{2}{*}{$\begin{array}{l}\text { STEC }(n=174) \\
97(55.7)\end{array}$} & \multirow{2}{*}{$\begin{array}{l}\operatorname{MDR}(n=106) \\
61(57.5)\end{array}$} & \multirow{2}{*}{$\begin{array}{l}\mathrm{ESBL}+(\mathrm{n}=71) \\
40(56.3)\end{array}$} \\
\hline Gender & Male & & & & \\
\hline No. (\%) & Female & $156(45.9)$ & $77(44.3)$ & $45(42.5)$ & $31(43.7)$ \\
\hline \multirow{3}{*}{$\begin{array}{l}\text { Age } \\
\text { No. (\%) }\end{array}$} & $\leq 6$ year & $126(37.1)$ & 71 (40.8) & 43 (40.6) & 26 (36.6) \\
\hline & 7-30 year & $105(30.9)$ & 52 (29.9) & $31(29.2)$ & $25(35.2)$ \\
\hline & > 30 year & 109 (32.0) & $51(29.3)$ & $32(30.2)$ & $20(28.2)$ \\
\hline
\end{tabular}

STEC Shiga toxin-producing Escherichia coli, MDR multidrug resistant, ESBL extended spectrum $\beta$-lactamase 
Table 3 Antimicrobial susceptibility patterns of STEC isolates

\begin{tabular}{|c|c|c|c|c|c|c|c|c|c|c|}
\hline \multirow[t]{2}{*}{ Antibiotic } & \multicolumn{3}{|c|}{ Total $(n=174)$} & \multicolumn{3}{|c|}{$E S B L-(n=103)$} & \multicolumn{3}{|c|}{$\mathrm{ESBL}+(\mathrm{n}=71)$} & \multirow[t]{2}{*}{$P$-value } \\
\hline & R No. (\%) & | No. (\%) & S No. (\%) & R No. (\%) & I No. (\%) & S No. (\%) & R No. (\%) & I No. (\%) & S No. (\%) & \\
\hline Cefotaxime & $77(44.3)$ & $3(1.7)$ & $94(54.0)$ & $7(6.8)$ & $2(1.9)$ & $94(91.3)$ & 70 (98.6) & $1(1.4)$ & - & $<0.001$ \\
\hline Ceftazidime & $49(28.2)$ & $20(11.5)$ & $105(60.3)$ & $5(4.9)$ & $3(2.9)$ & $95(92.2)$ & $44(62.0)$ & $17(23.9)$ & $10(14.1)$ & $<0.001$ \\
\hline Piperacillin-tazo & $1(0.6)$ & $11(6.3)$ & $162(93.1)$ & - & $5(4.9)$ & $98(95.1)$ & $1(1.4)$ & $6(8.2)$ & $64(90.1)$ & 0.298 \\
\hline Ertapenem & $1(0.6)$ & - & 173 (99.4) & $1(1.0)$ & - & $102(99.0)$ & - & - & $71(100)$ & 0.405 \\
\hline Imipenem & - & $1(0.6)$ & 173 (99.4) & - & $1(1.0)$ & $102(99.0)$ & - & - & $71(100)$ & 0.405 \\
\hline Ciprofloxacin & $44(25.3)$ & $10(5.74)$ & $120(69.0)$ & 14 (13.6) & $4(3.9)$ & $85(82.5)$ & $30(42.4)$ & $6(8.2)$ & $35(49.4)$ & $<0.001$ \\
\hline Levofloxacin & $42(24.1)$ & $3(1.7)$ & $129(74.2)$ & $10(9.7)$ & $2(1.94)$ & $91(88.4)$ & $32(45.1)$ & $1(1.4)$ & $38(53.5)$ & $<0.001$ \\
\hline Amikacin & $1(0.6)$ & $6(3.4)$ & $167(96.0)$ & - & $3(2.9)$ & $100(97.1)$ & $1(1.4)$ & $3(4.2)$ & $67(94.4)$ & 0.429 \\
\hline Tetracyclines & $100(57.5)$ & $4(2.3)$ & $70(40.2)$ & $44(42.7)$ & $3(2.9)$ & $56(54.4)$ & $56(78.9)$ & $1(1.4)$ & $14(19.7)$ & $<0.001$ \\
\hline Ampicillin & $119(68.4)$ & $5(2.9)$ & $50(28.7)$ & 49 (47.6) & $5(4.9)$ & $49(47.6)$ & 70 (98.6) & - & $1(1.4)$ & $<0.001$ \\
\hline Trimethoprim-sulfa & $104(59.8)$ & - & $70(40.2)$ & $43(41.7)$ & - & $60(58.3)$ & $61(85.9)$ & - & $10(14.1)$ & $<0.001$ \\
\hline
\end{tabular}

$R$ resistant, I intermediate, S sensitive, ESBL extended spectrum $\beta$-lactamase, STEC Shiga toxin-producing Escherichia coli

Table 4 Antibiotic resistance profile in 106 MDR isolates

\begin{tabular}{lll}
\hline Antibiotic profile & $\begin{array}{l}\text { No. of antibiotic } \\
\text { groups }\end{array}$ & No. (\%) \\
\hline CTX/CAZ/CIP/LVX/Te/AM/SXT & 5 & $19(17.9)$ \\
CTX/CIP/LVX/Te/AM/SXT & 5 & $8(7.6)$ \\
CTX/CAZ/CIP/LVX/AM/SXT & 4 & $2(1.9)$ \\
CTX/CAZ/CIP/LVX/Te/AM & 4 & $1(0.9)$ \\
CTX/CAZ/Te/AM/SXT & 4 & $14(13.2)$ \\
CTX/CIP/LVX/AM/SXT & 4 & $2(1.9)$ \\
CIP/LVX/Te/AM/SXT & 4 & $4(3.8)$ \\
CTX/Te/AM/SXT & 4 & $12(11.3)$ \\
CIP/Te/AN/SXT & 4 & $1(0.9)$ \\
CTX/CAZ/CIP/LVX/AM & 3 & $1(0.9)$ \\
CTX/CAZ/AM/SXT & 3 & $6(5.7)$ \\
CTX/CAZ/TZP/AM & 3 & $1(0.9)$ \\
CTX//CIP/LVX/AM & 3 & $1(0.9)$ \\
CIP/LVX/Te/SXT & 3 & $1(0.9)$ \\
CTX/Te/AM & 3 & $4(3.8)$ \\
CTX/AM/SXT & 3 & $2(1.9)$ \\
CIP/Te/AM & 3 & $1(0.9)$ \\
CIP/AM/SXT & 3 & $1(0.9)$ \\
LVX/Te/SXT & 3 & $1(0.9)$ \\
Te/AM/SXT & 3 & $24(22.7)$ \\
\hline AM ImPICII/AN amikan & &
\end{tabular}

AM ampicillin, $A N$ amikacin, CAZ ceftazidime, CIP ciprofloxacin, CTX cefotaxime, LVX levofloxacin, STX trimethoprim + sulfamethoxazole, Te tetracyclines, TZP piperacillin + tazobactam, MDR multidrug resistant

highest co-existence rate of $\beta$-lactamase producing genes belonged to blaCTX-M9/blaTEM, followed by blaOXA/ blaTEM, blaCTX-M9/blaSHV, blaCTX-M9/blaOXA and blaSHV/blaTEM (31.0\%, 23.9\%, 19.7\%, 16.9\% and 16.9\%, respectively). The Molecular Patterns are demonstrated in Table 5.
Table 5 Molecular pattern of 71 ESBL positive strains

\begin{tabular}{lc}
\hline Molecular Pattern & No. $(\%)$ \\
\hline CTX-M9/SHV/OXA/TEM & $3(4.2)$ \\
CTX-M9/SHV/OXA & $2(2.8)$ \\
CTX-M9/SHV/TEM & $3(4.2)$ \\
CTX-M9/OXA/TEM & $6(8.5)$ \\
SHV/OXA/TEM & $1(1.4)$ \\
CTX-M9/SHV & $6(8.5)$ \\
CTX-M9/OXA & $1(1.4)$ \\
CTX-M9/TEM & $10(14.1)$ \\
SHV/TEM & $6(8.5)$ \\
OXA/TEM & $7(9.9)$ \\
CTX-M9 & $4(5.6)$ \\
SHV & $4(5.6)$ \\
OXA & $1(1.4)$ \\
TEM & $13(18.3)$ \\
None & $4(5.6)$ \\
\hline
\end{tabular}

ESBL extended spectrum $\beta$-lactamase

\section{Phylogenetic analysis}

The 174 STEC isolates were assigned into different phylogroups according to Clermont's quadruplex scheme (Fig. 1). The phylotyping results revealed Group C as the most frequent Group (21.3\% occurrence), followed by Groups E (15.5\%), B2 (14.9\%), A (12.1\%) and B1 (9.2\%). The prevalence of Groups D and F was 2.3\%; moreover approximately $18.9 \%$ of the isolates remained unclassified. The MDR and ESBL producing isolates represented more affiliation with Group E (Fig. 2). 


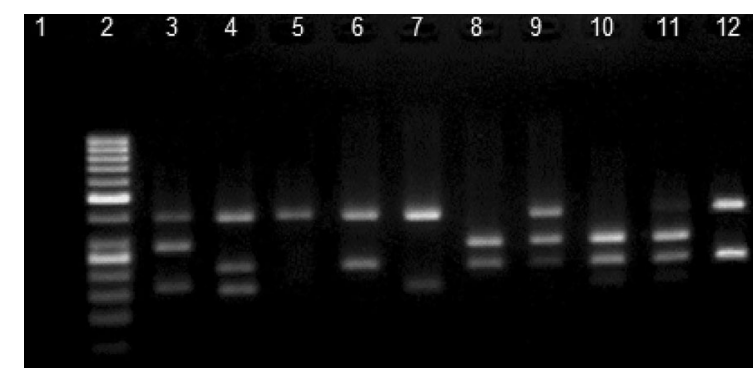

Fig. 1 Phylo-typing of STEC strains. arpA (400 bp), chuA (288 bp), yjaA (211 bp) and TspE4.C2 (152 bp). Lane 1, negative control; lane 2, molecular weight marker (50 bp, Fermentas); lane 3, group D (+ + $-+)$; lane 4, unknown $(+-++)$; lane 5 , group $\mathrm{A}(+---)$; lanes 6\&12, group C (+ - + -); lane 7, group B1 $(+--+)$ ) lanes 8\&10, group B2 $(-++-)$ and lanes 9\&11, group $\mathrm{E}(+++-)$

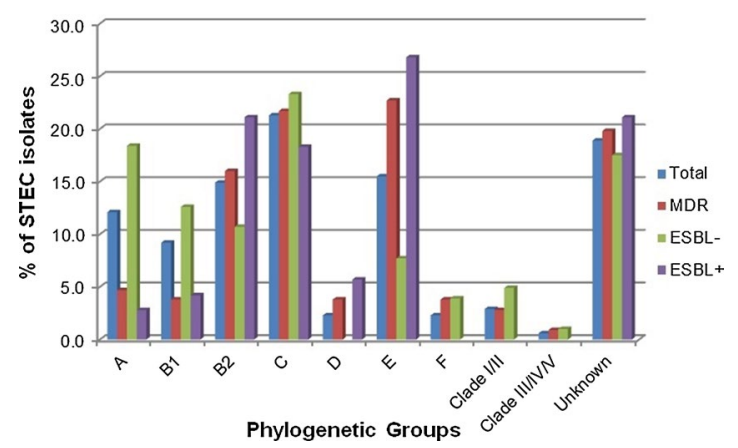

Fig. 2 Distribution of Phylogenetic Groups among STEC isolates. STEC Shiga toxin-producing Escherichia coli, MDR multidrug resistant, ESBL extended spectrum $\beta$-lactamase

\section{MLST analysis}

According to virulence genes, ESBL genes and resistance profile, total of 25 isolates; 18 STEC and 7 EPEC (previously published data), were analyzed using Pasteur MLST scheme. Examining gene sequences of the strains and assigning specific alleles for each locus resulted in the identification of diverse sequence types (STs) (Table 6). The tested isolates exhibited 21 sequence types among which the most frequent ones were ST506 (3 isolates), ST77 (2 isolates) and ST1007 (2 isolates). ST506 were represented by ESBL producers.

\section{Discussion}

Of the $340 \mathrm{E}$. coli isolates in this study, 174 strains were identified as STEC among which prevalence of stx 1 and stx 2 genes was $98.3 \%$ and $5.7 \%$, respectively. Although in general infection of humans by st $2 a$ may cause more severe clinical outcomes [2, 21], a recent study in England indicated that presence of stx1a can also be associated with severe disease [21]. The current study provides results of antibacterial assessment; molecular evaluation of ESBL-producing isolates and phylogenetic groups of STEC strains associated with diarrheal patients in Iran. The patients comprised of $55.7 \%$ males and $44.3 \%$ females distributed among all age groups with higher incident in $\leq 6$ years, which was similar to findings of other studies $[22,23]$.

Overuse of antibiotics with and/or without prescription is responsible for emergence of multidrug resistance among clinical isolates, which is a serious public health issue and can create therapeutic difficulties for patients. The findings of this study show high levels of resistance to ampicillin, trimethoprim-sulfamethoxazole and tetracycline among STEC, which is in agreement with previous findings in Japan, China, South Africa, Iran, Mexico and Michigan [24-29]. Also relatively lower levels of resistance to cefotaxime, ceftazidime, ciprofloxacin and levofloxacin was revealed, a finding which was similar to those reported by others [30,31], and opposite to that reported by Zhang et al. in china [25]. Among antibiotics tested, highest sensitivity was toward imipenem and ertapenem with $99.4 \%$, followed by amikacin and piperacillin-tazobactam with $96.0 \%$ and $93.1 \%$, respectively. Similar pattern was reported from India [30]. The prevalence of MDR was 60.9\%, which was both lower [25] and higher [24] than results reported by others. Furthermore, almost all of the ESBL-producing STEC strains were MDR.

The presence of ESBL-producing isolates in clinical samples is worrisome in both developed and developing countries. Rapid expansion of ESBL positive isolates highly affects the activity of broad-spectrum antibiotics, creating major therapeutic difficulties [32]. Also, the involvement of horizontal gene transfer in the spread of resistance determinants and the fact that ESBL encoding plasmids also carry resistance genes for other antimicrobial drugs poses a serious challenge. Therefore, the detection of gene variants in $\beta$-lactamase-producing bacteria is essential information for the appropriate and effective treatment of patients. In the current study, the $71 \mathrm{ESBL}-$ producing STEC isolates were analyzed by PCR for the presence of $4 \beta$-lactamase genes. The blaTEM was more common, followed by blaCTX-M9, blaSHV and blaOXA. In respect to higher prevalence of blaTEM, our findings are similar with a study from India [33], whereas in other studies blaCTX-M was more common [30, 31].

Phylogenetic analysis of $E$. coli clinical strains provides information about the frequency of occurrence in the environment. In this study, we determined the phylogenetic group of 174 STEC strains isolated from the stool of diarrheal patients and showed that the majority of STEC strains belonged to 1 of 5 phylogroups; C, E, B2, A and B1, while ESBL positive and MDR strains represented more affiliation with Group E. Furlan et al. [34] assessed 
Table 6 Characteristics of diarrheagenic Escherichia coli strains and their affiliation to sequence types

\begin{tabular}{|c|c|c|c|c|c|c|}
\hline Isolate & $P G$ & Virulence gene & Resistance profile & $\beta$-lactamase gene & PST & Allelic profile ${ }^{b}$ \\
\hline B1013053 & clade V & stx1 & Te, AM, SXT & - & $1005^{\mathrm{a}}$ & $152,189,7,132,162,127,130,77$ \\
\hline B2011071 & $\mathrm{F}$ & stx1 & CIP,LVX,Te, AM, SXT & - & $1011^{\mathrm{a}}$ & $13,148,194,16,12,25,90,19$ \\
\hline E3012101 & $E$ & stx1 & ESBL+, CTX,Te, AM,SXT & CTX,SHV,TEM & $1012^{\mathrm{a}}$ & $10,33,18,166,5,28,2,2$ \\
\hline E3021041 & $A$ & stx1 & ESBL+, CTX,CAZ,Te, AM,SXT & SHV,TEM & 353 & $11,3,4,3,15,1,4,40$ \\
\hline F4011011 & $A$ & stx1 & Te, AM, SXT & - & $1006^{\mathrm{a}}$ & $8,2,7,3,186,1,4,2$ \\
\hline H1012052 & $A$ & $\mathrm{st} \times 1, \mathrm{st} \times 2$ & ESBL+, CTX,Te, AM,SXT & SHV,TEM & 83 & $11,3,4,3,15,1,4,16$ \\
\hline H2012086 & $A$ & stx1,stx2,eae & ESBL+, CTX,Te, AM,SXT & SHV,TEM & 191 & $8,2,7,3,61,1,4,2$ \\
\hline H2O22075 & B2 & stx1 & ESBL+, CTX,CAZ,CIP,LVX,Te, AM, SXT & SHV,OXA,TEM & 43 & $9,1,15,7,4,9,6,9$ \\
\hline $\mathrm{H} 4022014$ & B2 & stx1 & sensitive & - & 53 & $1,7,1,9,20,20,1,6$ \\
\hline $\mathrm{H} 4022024$ & $E$ & eae & ESBL+, CTX,CAZ,Te, AM,SXT & SHV,TEM & $1013^{\mathrm{a}}$ & $10,2,149,17,18,116,16,40$ \\
\hline 12021071 & B2 & stx1 & ESBL+, CTX,Te, AM,SXT & CTX,TEM & 506 & $9,134,74,134,4,72,1,9$ \\
\hline 12022061 & B1 & stx1 & ESBL+, CTX,CAZ,Te, AM,SXT & CTX,TEM & 186 & $7,33,18,68,5,8,2,2$ \\
\hline$J 2022082$ & B1 & stx1,eae & sensitive & - & $1007^{a}$ & $25,3,4,146,78,29,2,5$ \\
\hline$J 2023073$ & $A$ & stx1,eae & $\mathrm{ESBL}+, \mathrm{CTX}, \mathrm{Te}, \mathrm{AM}, \mathrm{SXT}$ & OXA,TEM & 446 & $10,2,3,3,7,1,4,2$ \\
\hline$J 4011022$ & $\mathrm{D}$ & stx1, eae & ESBL+, CTX,CAZ,Te, AM,SXT & OXA,TEM & 3 & $3,8,5,11,8,3,5,3$ \\
\hline$J 4011121$ & B1 & stx2 & $\mathrm{CTX}, \mathrm{Te}, \mathrm{AM}$ & - & $1007^{a}$ & $25,3,4,146,78,29,2,5$ \\
\hline$J 4021026$ & B1 & eae & Te, AM, SXT & - & $1009^{a}$ & $5,3,4,52,84,1,16,66$ \\
\hline K3012111 & B2 & stx1 & $\mathrm{ESBL}+, \mathrm{CTX}, \mathrm{CAZ}, \mathrm{TZP}, \mathrm{AM}$ & CTX,SHV,OXA,TEM & 506 & $9,134,74,134,4,72,1,9$ \\
\hline K4012127 & $A$ & eae & AM, SXT & - & 367 & $8,104,7,3,7,1,4,2$ \\
\hline L3013091 & $\mathrm{D}$ & $s t \times 1, s t \times 2$ & $\mathrm{ESBL}+, \mathrm{CTX}, \mathrm{Te}, \mathrm{AM}$ & NONE & $1008^{\mathrm{a}}$ & $3,8,5,11,161,3,5,3$ \\
\hline N1022052 & $\mathrm{D}$ & eae & $\mathrm{ESBL}+, \mathrm{CTX}, \mathrm{AM}$ & CTX,SHV,TEM & 77 & $3,43,31,33,8,3,5,11$ \\
\hline N1022054 & B2 & eae & $\mathrm{ESBL}+, \mathrm{CTX}, \mathrm{CAZ}, \mathrm{Te}, \mathrm{AM}, \mathrm{SXT}$ & CTX,SHV,OXA,TEM & 506 & $9,134,74,134,4,72,1,9$ \\
\hline N3013101 & B1 & stx1 & Te, AM, SXT & - & 636 & $7,3,3,68,74,7,4,5$ \\
\hline O2021062 & $A$ & eae & ESBL+, CTX,CAZ,TZP,CIP,LVX,Te, AM,SXT & CTX,SHV,TEM & $1014^{\mathrm{a}}$ & $10,2,3,163,18,116,16,22$ \\
\hline 04011022 & $\mathrm{D}$ & eae & Te, AM, SXT & - & 77 & $3,43,31,33,8,3,5,11$ \\
\hline
\end{tabular}

$P G$ polygenetic group, ESBL extended spectrum $\beta$-lactamase, $P S T$ pasteur sequence type

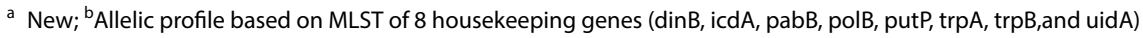

the prevalence of phylogenetic groups in STEC isolated from sheep and revealed that group $\mathrm{E}$ was most prevalent, followed by B1, A and B2. Jajarmi et al. [35] reported that phylogenetic group B1 then A were the most prevalent in STEC strains isolated from goats. Phylogenetic groups A and B2 were also reported by Ahumada-Santos et al. as the most frequent phylogroups among children with diarrheagenic E. coli [36]. These differences in distribution of phylogenetic groups in different studies may be due to varying conditions in sampling areas.

In current study, we also used Pasteur MLST scheme to analyze the diarrheagenic $E$. coli population structure using the sequences of eight housekeeping genes, and MLST results indicated a highly diverse sequence types (STs), which are in accordance with other findings [37, 38].

\section{Conclusion}

Escherichia coli isolates in this study have demonstrated high levels of resistance to various antimicrobial agents. The emergences of ESBL-producing isolates were detected, which poses a serious public health challenges. Our results also revealed worrying increase in the prevalence of MDR among ESBL-producing STEC, especially those affiliated to phylogroup E. These findings emphasize the health risks and difficulties that could be encountered in eradicating STEC infections. Thus more research should be directed towards periodical surveillance studies to screen/identify patients that are carriers of ESBL-producing bacteria, in order to develop an effective antibiotic therapy guideline. Moreover, to prevent the further spread of MDR isolates, empirical treatments and overuse of antibiotics by patients should be discouraged.

\section{Abbreviations}

STEC: Shiga toxin-producing Escherichia coli; stx: Shiga toxin; HC: Hemorrhagic colitis; HUS: Hemolytic uremic syndrome; ESBL: Extended-spectrum $\beta$-lactamase; MLST: Multi-locus sequence types; PCR: Polymerase chain reaction; MDR: Multidrug resistance; eae: Intimin; CLSI: Clinical and laboratory standards institute; ST: Sequence type; EPEC: Enteropathogenic Escherichia coli. 


\section{Acknowledgements}

We thank the team of curators of the Institute Pasteur MLST and wholegenome MLST databases for curating the data and making them publicly available at http://bigsdb.web.pasteur.fr/.

\section{Authors' contributions}

EJ performed the experiments, contributed to data collection /analysis, and drafted the manuscript. MO contributed to the study design, and MLST analysis. SB designed /supervised the study, and edited the manuscript. All authors read and approved the final manuscript.

\section{Funding}

This work was financially supported by Pasteur Institute of Iran (Grant No. 1045). The funders had no role in study design and execution, decision to publish, or preparation of the manuscript.

\section{Availability of data and materials}

The datasets used and/or analyzed during the current study are available from the corresponding author on reasonable request.

\section{Declarations}

\section{Ethics approval and consent to participate}

All sampling protocols in this study were approved by Pasteur Institute of Iran ethics committee (ethical code: IR.PII.REC.1397.003).

\section{Consent for publication}

Not applicable.

\section{Competing interests}

The authors declare that they have no competing interests in this work.

\section{Author details}

${ }^{1}$ Molecular Biology Department, Pasteur Institute of Iran, Tehran, Iran.

${ }^{2}$ National Escherichia Coli Reference Laboratory, Pasteur Institute of Iran,

Tehran, Iran.

Received: 2 March 2021 Accepted: 10 April 2021

Published online: 15 April 2021

\section{References}

1. Gyles C. Shiga toxin-producing Escherichia coli: an overview. J Anim Sci. 2007. https://doi.org/10.2527/jas.2006-508.

2. Smith JL, Fratamico PM, Gunther IVNW. Shiga toxin-producing Escherichia coli. In: Advances in applied microbiology. New York: Elsevier; 2014. p. 145-97.

3. Mir RA, Kudva IT. Antibiotic-resistant Shiga toxin-producing Escherichia coli: an overview of prevalence and intervention strategies. Zoonoses Public Health. 2019. https://doi.org/10.1111/zph.12533.

4. Erb A, Stürmer T, Marre R, Brenner H. Prevalence of antibiotic resistance in Escherichia coli: overview of geographical, temporal, and methodological variations. Eur J Clin Microbiol Infect Dis. 2007. https://doi.org/10.1007/ s10096-006-0248-2.

5. Babic M, Hujer AM, Bonomo RA. What's new in antibiotic resistance? Focus on beta-lactamases. Drug Resist Updates. 2006. https://doi.org/10. 1016/j.drup.2006.05.005.

6. Bush K, Bradford PA. Epidemiology of $\beta$-lactamase-producing pathogens. Clin Microbiol Rev. 2020. https://doi.org/10.1128/CMR.00047-19.

7. Alves H, de Cruz F, de Assis P, Pessoa JD, Trevelin L, de Leal A, et al. Antibiotic resistance among Escherichia coli: isolates and novel approaches to the control of E. coli infections. In: Recent advances on physiology, pathogenesis and biotechnological applications. Rijeka: INTECH; 2017. https://doi.org/10.5772/67400.

8. Clermont O, Christenson JK, Denamur E, Gordon DM. The C lermont E scherichia coli phylo-typing method revisited: improvement of specificity and detection of new phylo-groups. Environ Microbiol Rep. 2013. https:// doi.org/10.1111/1758-2229.12019.
9. Reid CJ, Wyrsch ER, Chowdhury PR, Zingali T, Liu M, Darling AE, et al. Porcine commensal Escherichia coli: a reservoir for class 1 integrons associated with IS26. Microbial genomics. 2017. https://doi.org/10.1099/ mgen.0.000143.

10. Nowrouzian FL, Clermont O, Edin M, Östblom A, Denamur E, Wold AE, et al. Escherichia coli B2 phylogenetic subgroups in the infant gut microbiota: predominance of uropathogenic lineages in swedish infants and enteropathogenic lineages in Pakistani Infants. Appl Environ Microbiol. 2019. https://doi.org/10.1128/AEM.01681-19.

11. Mosquito S, Pons MJ, Riveros M, Ruiz J, Ochoa TJ. Diarrheagenic Escherichia coli phylogroups are associated with antibiotic resistance and duration of diarrheal episode. Sci World J. 2015. https://doi.org/10.1155/2015/ 610403.

12. Garcia LS. Clinical microbiology procedures handbook. 3rd ed. Washington, DC: ASM Press; 2010.

13. Müller D, Greune L, Heusipp G, Karch H, Fruth A, Tschäpe H, et al. Identification of unconventional intestinal pathogenic Escherichia coli isolates expressing intermediate virulence factor profiles by using a novel single-step multiplex PCR. Appl Environ Microbiol. 2007. https://doi.org/ 10.1128/AEM.02855-06.

14. Carneiro L, Lins M, Garcia F, Silva A, Mauller P, Alves G, et al. Phenotypic and genotypic characterisation of Escherichia coli strains serogrouped as enteropathogenic E. coli (EPEC) isolated from pasteurised milk. Int J Food Microbiol. 2006. https://doi.org/10.1016/j.ijfoodmicro.2005.10.010.

15. Wayne P. Performance standards for antimicrobial susceptibility testing, CLSI supplement M100S. 26th ed. Wayne: Clinical and Laboratory Standards Institute; 2016. p. 256.

16. Basak S, Singh P, Rajurkar M. Multidrug resistant and extensively drug resistant bacteria: a study. J Pathog. 2016. https://doi.org/10.1155/2016/ 4065603

17. Navon-Venezia S, Chmelnitsky I, Leavitt A, Carmeli Y. Dissemination of the CTX-M-25 family $\beta$-lactamases among Klebsiella pneumoniae, Escherichia coli and Enterobacter cloacae and identification of the novel enzyme CTXM-41 in Proteus mirabilis in Israel. J Antimicrob Chemother. 2008. https:// doi.org/10.1093/jac/dkn182.

18. Van TTH, Chin J, Chapman T, Tran LT, Coloe PJ. Safety of raw meat and shellfish in Vietnam: an analysis of Escherichia coli isolations for antibiotic resistance and virulence genes. Int J Food Microbiol. 2008. https://doi. org/10.1016/j.jijoodmicro.2008.03.029.

19. Gheorghe I, Czobor I, Chifiriuc MC, Borcan E, Ghiță C, Banu O, et al. Molecular screening of carbapenemase-producing Gram-negative strains in Romanian intensive care units during a one year survey. J Med Microbiol. 2014. https://doi.org/10.1099/jmm.0.074039-0.

20. Maynou G, Migura-Garcia L, Chester-Jones H, Ziegler D, Bach A, Terré M. Effects of feeding pasteurized waste milk to dairy calves on phenotypes and genotypes of antimicrobial resistance in fecal Escherichia coli isolates before and after weaning. J Dairy Sci. 2017. https://doi.org/10.3168/jds. 2017-13040.

21. Byrne L, Adams N, Jenkins C. Association between Shiga Toxin-producing Escherichia coli O157: H7 stx gene subtype and disease Severity, England, 2009-2019. Emerg Infect Dis. 2020. https://doi.org/10.3201/eid2610. 200319.

22. Majowicz SE, Scallan E, Jones-Bitton A, Sargeant JM, Stapleton J, Angulo FJ, et al. Global incidence of human Shiga toxin-producing Escherichia coli infections and deaths: a systematic review and knowledge synthesis. Foodborne Pathog Dis. 2014. https://doi.org/10.1089/fpd.2013.1704.

23. Käppeli U, Hächler H, Giezendanner N, Beutin L, Stephan R. Human infections with non-O157 Shiga toxin-producing Escherichia coli, Switzerland, 2000-2009. Emerg Infect Dis. 2011. https://doi.org/10.3201/eid1702. 100909.

24. Kubomura A, Sekizuka T, Onozuka D, Murakami K, Kimura H, Sakaguchi $\mathrm{M}$, et al. Truncated class 1 integron gene cassette arrays contribute to antimicrobial resistance of diarrheagenic Escherichia coli. Biomed Res Int. 2020. https://doi.org/10.1155/2020/4908189.

25. Zhang S-X, Zhou Y-M, Tian L-G, Chen J-X, Tinoco-Torres R, Serrano E, et al. Antibiotic resistance and molecular characterization of diarrheagenic Escherichia coli and non-typhoidal Salmonella strains isolated from infections in Southwest China. Infect Dis Poverty. 2018. https://doi.org/10. 1186/s40249-018-0427-2.

26. Omolajaiye S, Afolabi K, Iweriebor B. Pathotyping and antibiotic resistance profiling of Escherichia coli isolates from children with acute diarrhea in 
amatole district municipality of Eastern Cape, South Africa. BioMed Res Int. 2020. https://doi.org/10.1155/2020/4250165.

27. Abbasi E, Mondanizadeh M, van Belkum A, Ghaznavi-Rad E. Multi-drugresistant diarrheagenic Escherichia coli pathotypes in pediatric patients with gastroenteritis from central Iran. Infect Drug Resist. 2020. https://doi. org/10.2147/IDR.S247732.

28. Amézquita-López BA, Quiñones B, Soto-Beltrán M, Lee BG, Yambao JC Lugo-Melchor OY, et al. Antimicrobial resistance profiles of Shiga toxinproducing Escherichia coli $\mathrm{O} 157$ and Non-O157 recovered from domestic farm animals in rural communities in Northwestern Mexico. Antimicrob Resist Infect Control. 2016. https://doi.org/10.1186/s13756-015-0100-5.

29. Mukherjee S, Mosci RE, Anderson CM, Snyder BA, Collins J, Rudrik JT, et al. Antimicrobial drug-resistant Shiga toxin-producing Escherichia coli infections, Michigan, USA. Emerg Infect Dis. 2017. https://doi.org/10.3201/ eid2309.170523.

30. Mandal A, Sengupta A, Kumar A, Singh UK, Jaiswal AK, Das P, et al. Molecular epidemiology of extended-spectrum $\beta$-lactamase-producing Escherichia coli pathotypes in diarrheal children from low socioeconomic status communities in Bihar, India: emergence of the CTX-M Type. Infect Dis Res Treat. 2017. https://doi.org/10.1177/1178633617739018.

31. Haghighatpanah M, Nejad ASM, Mojtahedi A, Amirmozafari N, Zeighami $H$. Detection of extended-spectrum $\beta$-lactamase (ESBL) and plasmidborne blaCTX-M and blaTEM genes among clinical strains of Escherichia coli isolated from patients in the north of Iran. J Glob Antimicrob Resist. 2016. https://doi.org/10.1016/j.jgar.2016.08.005.

32. Adler A, Katz DE, Marchaim D. The continuing plague of extended-spectrum $\beta$-lactamase-producing Enterobacteriaceae infections. Infect Dis Clin. 2016. https://doi.org/10.1016/j.idc.2016.02.003.

33. Singh T, Singh PK, Das S, Wani S, Jawed A, Dar SA. Transcriptome analysis of beta-lactamase genes in diarrheagenic Escherichia coli. Sci Rep. 2019. https://doi.org/10.1038/s41598-019-40279-1.
34. Furlan JPR, Gallo IFL, de Campos ACLP, Navarro A, Kobayashi RKT, Nakazato G, et al. Characterization of non-O157 Shiga toxin-producing Escherichia coli (STEC) obtained from feces of sheep in Brazil. World J Microbiol Biotechnol. 2019. https://doi.org/10.1007/s11274-019-2712-z.

35. Jajarmi M, Askari Badouei M, Ghanbarpour R, Karmostaji A, Alizade H. Antimicrobial resistance patterns and phylogenetic analysis of Shiga toxin-producing Escherichia coli strains from goats using both clermont phylogenetic schemes. Bulgarian J Vet Med. 2019. https://doi.org/10. 15547/bjvm.2019-0055.

36. Ahumada-Santos YP, Báez-Flores ME, Díaz-Camacho SP, de Jesús U-B, Eslava-Campos CA, Parra-Unda JR, et al. Association of phylogenetic distribution and presence of integrons with multidrug resistance in Escherichia coli clinical isolates from children with diarrhoea. J Infect Public Health. 2020. https://doi.org/10.1016/j.jiph.2019.11.019.

37. Cadona JS, Bustamante AV, González J, Sanso AM. Genetic relatedness and novel sequence types of Non-O157 Shiga toxin-producing Escherichia coli strains isolated in Argentina. Front Cell Infect Microbiol. 2016. https://doi.org/10.3389/fcimb.2016.00093.

38. Fierz L, Cernela N, Hauser E, Nüesch-Inderbinen M, Stephan R. Human infections with Shiga toxin-producing Escherichia coli, Switzerland, 2010-2014. Front Microbiol. 2017. https://doi.org/10.3389/fmicb.2017. 01471.

\section{Publisher's Note}

Springer Nature remains neutral with regard to jurisdictional claims in published maps and institutional affiliations.
Ready to submit your research? Choose BMC and benefit from:

- fast, convenient online submission

- thorough peer review by experienced researchers in your field

- rapid publication on acceptance

- support for research data, including large and complex data types

- gold Open Access which fosters wider collaboration and increased citations

- maximum visibility for your research: over $100 \mathrm{M}$ website views per year

At BMC, research is always in progress.

Learn more biomedcentral.com/submissions 